\title{
Prairie Dog Coloniality and Black-Footed Ferrets
}

\author{
Roger A. Powell \\ Ecology, Vol. 63, No. 6. (Dec., 1982), pp. 1967-1968.
}

Stable URL:

http://links.jstor.org/sici?sici=0012-9658\%28198212\%2963\%3A6\%3C1967\%3APDCABF\%3E2.0.CO\%3B2-O

Ecology is currently published by Ecological Society of America.

Your use of the JSTOR archive indicates your acceptance of JSTOR's Terms and Conditions of Use, available at

http://www.jstor.org/about/terms.html. JSTOR's Terms and Conditions of Use provides, in part, that unless you have obtained prior permission, you may not download an entire issue of a journal or multiple copies of articles, and you may use content in the JSTOR archive only for your personal, non-commercial use.

Please contact the publisher regarding any further use of this work. Publisher contact information may be obtained at http://www.jstor.org/journals/esa.html.

Each copy of any part of a JSTOR transmission must contain the same copyright notice that appears on the screen or printed page of such transmission.

The JSTOR Archive is a trusted digital repository providing for long-term preservation and access to leading academic journals and scholarly literature from around the world. The Archive is supported by libraries, scholarly societies, publishers, and foundations. It is an initiative of JSTOR, a not-for-profit organization with a mission to help the scholarly community take advantage of advances in technology. For more information regarding JSTOR, please contact support@jstor.org. 


\section{Notes and Comments}

Ecology, 63(6), 1982, pp. 1967-1968

(C) 1982 by the Ecological Society of America

\section{PRAIRIE DOG COLONIALITY AND BLACK-FOOTED FERRETS ${ }^{1}$}

\section{Roger A. Powell ${ }^{2}$}

Hoogland (1981) discussed the evolution of coloniality in prairie dogs (Cynomys spp.), concluding that coloniality evolved to reduce predation. He argued that differences in coloniality between white-tailed (C. leucurus) and black-tailed prairie dogs (C. ludovicianus) are due to habitat differences that facilitate different predator avoidance techniques. Hoogland minimized the importance of differences in predation pressure on the two prairie dog species by citing references that show that predators known to prey on one prairie dog species also prey on the other.

Fig. 1 shows the species ranges of black-tailed and white-tailed prairie dogs and the original range of the black-footed ferret (Mustela nigripes; Hall 1981), a specialist predator on prairie dogs. These range maps are consistent with the reports cited by Hoogland (Clark 1973, Torres 1973, Yannone 1973) to show that ferrets prey on both prairie dog species (though these reports do not specifically document ferret predation on whitetailed prairie dogs). The ferrets seen in white-tailed prairie dog towns were all at the edges of both species ranges. Thus, even though ferrets have been sighted in colonies of white-tailed prairie dogs, the range maps suggest a strong relationship between black-footed ferret predation and the differences in coloniality between the two prairie dog species.

At least two alternative hypotheses can explain the species ranges. First, dense prairie dog colonies may be better adapted than sparse colonies to detecting ferrets and therefore have evolved in the species whose range overlaps with that of the black-footed ferret. This assumes that the black-footed ferret species range is determined by some habitat (or other) characteristic independent of the prairie dog species. As Hoogland pointed out, since ferrets are largely nocturnal predators (Henderson et al. 1968, Hillman 1968), it is not clear how colony density of the diurnal prairie dogs could respond to predation by ferrets. Second, blackfooted ferrets may be dependent on a dense food source, in which case sparse colony density, facilitated by vegetation characteristics, may allow white-tailed prairie dogs to avoid ferret predation. This second hy-

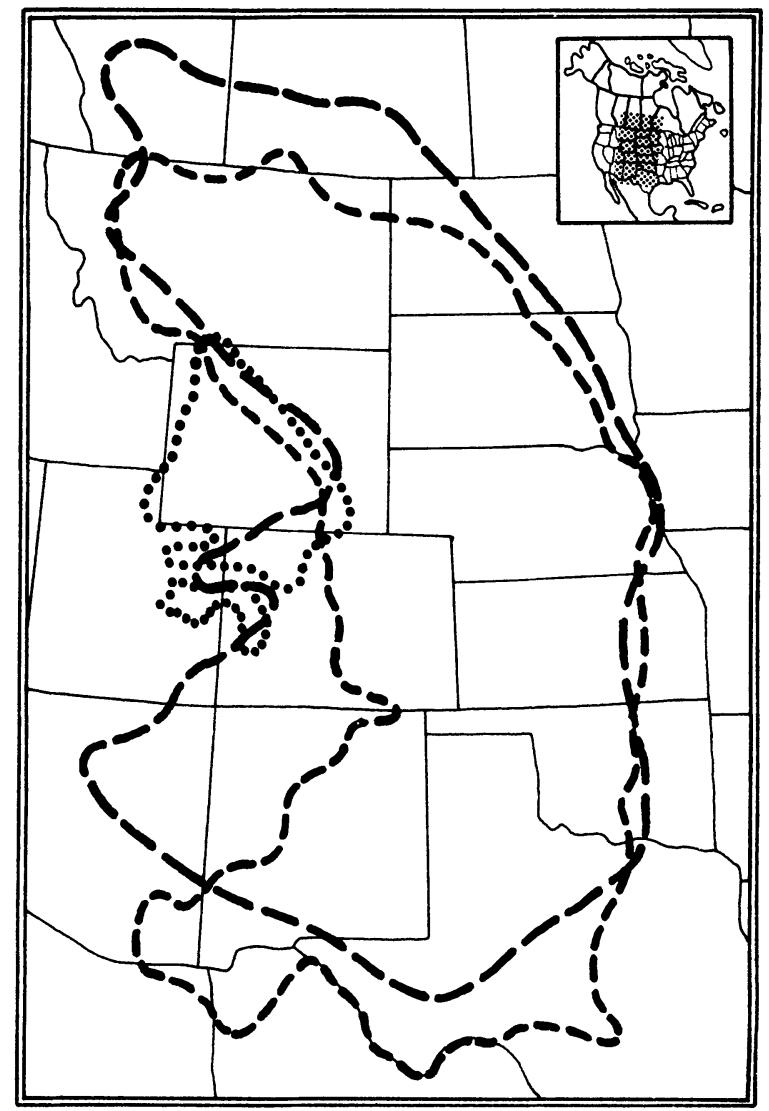

FIG. 1. Species ranges of the black-footed ferret (long dashes), black-tailed prairie dog (short dashes), and whitetailed prairie dog (dots) (redrawn from Hall 1981).

pothesis implies that white-tailed prairie dog sparse coloniality has been a limiting feature for the species range of the black-footed ferret. My own research on energetics of Siberian polecats (Mustela eversmanni) fed black-footed ferret diets indicates that ferrets can maintain populations only in prairie dog colonies with $>100$ reproducing prairie dogs (R. A. Powell, personal observation). This colony size is consistent with Hoogland's data for black-tailed prairie dog colonies but not for most white-tailed prairie dog colonies.

There is nothing in the species range characteristics shown in Fig. 1 that contradicts Hoogland's hypothesis that vegetation characteristics are important to differences in coloniality for the prairie dog species. However, Fig. 1 suggests that differences in predation by black-footed ferrets may have been more important than Hoogland concluded. It is unfortunate that hypotheses concerning black-footed ferret past range and 
past predatory habits are nearly impossible to test due to the ferret's present scarcity.

\section{Literature Cited}

Clark, T. W. 1973. Prairie dogs and black-footed ferrets in Wyoming. Pages 88-101 in R. L. Linder and C. N. Hillman, editors. Proceedings of the Black-footed Ferret and Prairie Dog Workshop. South Dakota State University, Brookings, South Dakota, USA.

Hall, E. R. 1981. The mammals of North America, second edition. J. Wiley and Sons, New York, New York, USA.

Henderson, F. R., P. F. Springer, and R. Adrian. 1968. The black-footed ferret in South Dakota. Technical Bulletin 4, South Dakota Department of Game, Fish, and Parks, Pierre, South Dakota, USA.

Hillman, C. N. 1968. Field observations of black-footeu ferrets in South Dakota. Transactions of the North American Wildlife and Natural Resources Conference 33:433443.

Hoogland, J. L. 1981. The evolution of coloniality in white- tailed and black-tailed prairie dogs (Sciuridae: Cynomys leucurus and C. ludovicianus). Ecology 62:252-272.

Torres, J. R. 1973. The future of the black-footed ferret in Colorado. Pages 27-33 in R. L. Linder and C. N. Hillman, editors. Proceedings of the Black-footed Ferret and Prairie Dog Workshop. South Dakota State University, Brookings, South Dakota, USA.

Yannone, V. D. 1973. The black-footed ferret in Montana. Pages 41-44 in R. L. Linder and C. N. Hillman, editors. Proceedings of the Black-footed Ferret and Prairie Dog Workshop. South Dakota State University, Brookings, South Dakota, USA.

\author{
${ }^{1}$ Manuscript received 28 September 1981; \\ revised 17 February 1982; \\ accepted 19 May 1982. \\ ${ }^{2}$ Department of Zoology, \\ North Carolina State University, \\ Raleigh, North Carolina 27607 USA.
}

Ecology, 63(6), 1982, pp. 1968-1969

(C) 1982 by the Ecological Society of America

\section{REPLY TO A COMMENT BY POWELL ${ }^{1}$}

John L. Hoogland ${ }^{2}$

Recently I examined the costs and benefits of coloniality in white-tailed and black-tailed prairie dogs (Cynomys leucurus and C. ludovicianus) (Hoogland $1979,1981)$. I also examined whether interspecific differences in predation pressure might explain why whitetails usually form small, sparsely populated colonies while black-tails usually form large, densely populated colonies. Because black-footed ferrets (Mustela nigripes) prey not only on black-tails but also on whitetails (references in Hoogland 1981), I concluded that the more extreme coloniality of black-tails cannot easily be explained as an adaptation specifically aimed at reducing predation by ferrets. Powell (1982) has challenged this conclusion. Because Hall (1981) and others (e.g., Cahalane 1954) have suggested that the geographic range of the ferret overlaps extensively with the black-tail range but only marginally with the whitetail range, Powell (1982) hypothesized that either (1) “. . . dense prairie dog colonies may be better adapted than sparse colonies to detecting ferrets and therefore have evolved in the species whose range overlaps with that of the black-footed ferret" or (2) ". . . black-foot- ed ferrets may be dependent on a dense food source, in which case sparse colony density, facilitated by vegetation characteristics, may allow white-tailed prairie dogs to avoid ferret predation." I have three comments in response to Powell's (1982) challenge.

First, Hall's (1981) range map for the ferret evidently does not include recent evidence of ferrets at white-tail colonies. Martin and Schroeder (1980), for example, recently found three ferret skulls at whitetail colonies near South Haystack, Uinta County, Wyoming, which is $>400 \mathrm{~km}$ from the nearest edge of the black-tail range map. Clark (1978) tabulated over 80 sightings of ferrets at or near white-tail colonies in western Wyoming where black-tails do not occur (see also Clark 1980, Clark and Campbell 1981); further, Clark's (1978) data suggest that, in Wyoming at least, ferrets are probably more common in western white-tail habitats than in eastern black-tail habitats. Finally, the largest population of ferrets ever found was discovered in 1981 among strictly white-tail habitats in northwestern Wyoming (M. Stromberg, personal communication). Thus, I disagree with Powell's (1982) claim that "The ferrets seen in white-tailed prairie dog towns were all at the edges of both species ranges." Perhaps the ferret range map has been biased in favor of the black-tail range map until now because ". . . black-tail colonies are larger, more numerous, and more conspicuous than are white-tail colonies, and are therefore more likely to attract the attention that is necessary for the detection of a preda- 
http://www.jstor.org

\section{LINKED CITATIONS \\ - Page 1 of 1 -}

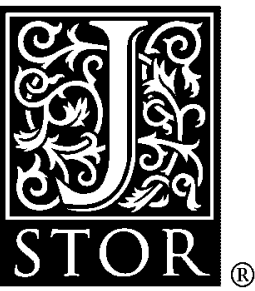

You have printed the following article:

Prairie Dog Coloniality and Black-Footed Ferrets

Roger A. Powell

Ecology, Vol. 63, No. 6. (Dec., 1982), pp. 1967-1968.

Stable URL:

http://links.jstor.org/sici?sici=0012-9658\%28198212\%2963\%3A6\%3C1967\%3APDCABF\%3E2.0.CO\%3B2-O

This article references the following linked citations. If you are trying to access articles from an off-campus location, you may be required to first logon via your library web site to access JSTOR. Please visit your library's website or contact a librarian to learn about options for remote access to JSTOR.

\section{Literature Cited}

The Evolution of Coloniality in White-tailed and Black-tailed Prairie Dogs (Sciuridae: Cynomys Leucurus and C. Ludovicianus)

John L. Hoogland

Ecology, Vol. 62, No. 1. (Feb., 1981), pp. 252-272.

Stable URL:

http://links.jstor.org/sici?sici=0012-9658\%28198102\%2962\%3A1\%3C252\%3ATEOCIW\%3E2.0.CO\%3B2-6 